\title{
HTLV-1 inserts an ectopic CTCF-binding site into the human genome
}

\author{
Yorifumi Satou ${ }^{1,2,3^{*}}$, Miyazato Paola ${ }^{2,3}$, Ko Ishihara ${ }^{2}$, Asami Fukuda ${ }^{2,3}$, Kisato Nosaka², Takehisa Watanabe², \\ Aileen Rowan ${ }^{1}$, Mitsuyoshi Nakao², Charles RM Bangham¹ \\ From 17th International Conference on Human Retroviruses: HTLV and Related Viruses \\ Trois Ilets, Martinique. 18-21 June 2015
}

HTLV-1 genes are encoded on both strands of the provirus, such as tax in the plus and HBZ in the minus strand. The HBZ gene is constitutively expressed from the negative strand of the integrated provirus, whereas plus-strand expression, required for viral propagation to uninfected cells, is expressed only intermittently in vivo, perhaps to escape from host immune surveillance. However, it remains unknown what regulates this pattern of proviral transcription in vivo. We have found that CTCF binds to the HTLV-1 provirus. CTCF is a DNA-binding protein that plays a fundamental role in controlling higher-order chromatin structure and gene expression in vertebrates. We identified several candidate regions for CTCF binding in the HTLV-1 genome. Chromatin immunoprecipitation assays showed that CTCF bound selectively to the $\mathrm{pX}$ region of HTLV-1. Furthermore, electromobility shift assays revealed that CTCF bound directly to the $\mathrm{pX}$ DNA sequence. Consistent with the CTCF binding, there was a sharp border of histone modification patterns at the $\mathrm{pX}$ region, consistent with CTCF's role as a chromatin insulator. Finally, the CTCF-binding region (1bp) showed enhancer-blocking activity. The CTCF binding and epigenetic border were detectable not only in HTLV-1 cell lines and ATL cell lines but also in fresh PBMCs of ATL patients. These observations suggest that CTCF plays a central role in the regulation of HTLV-1 transcription.

\#Poster award winnder - 1st place

\section{Authors' details}

'Department of Immunology, Imperial College London, London W2 1PG, UK. ${ }^{2}$ Kumamoto University, Kumamoto, 860-0811, Japan. ${ }^{3}$ International Research

\footnotetext{
* Correspondence: y-satou@kumamoto-u.ac.jp

'Department of Immunology, Imperial College London, London W2 1PG, UK
} Full list of author information is available at the end of the article
Center for Medical Sciences (IRCMS), Kumamoto University, Kumamoto, 8600811, Japan.

Published: 28 August 2015

doi:10.1186/1742-4690-12-S1-P12

Cite this article as: Satou et al: HTLV-1 inserts an ectopic CTCF-binding site into the human genome. Retrovirology 2015 12(Suppl 1):P12.
Submit your next manuscript to BioMed Central and take full advantage of:

- Convenient online submission

- Thorough peer review

- No space constraints or color figure charges

- Immediate publication on acceptance

- Inclusion in PubMed, CAS, Scopus and Google Scholar

- Research which is freely available for redistribution

Submit your manuscript at www.biomedcentral.com/submit

\section{() Biomed Central}

( Biomed Central

c 2015 Satou et al. This is an Open Access article distributed under the terms of the Creative Commons Attribution License (http:// creativecommons.org/licenses/by/4.0), which permits unrestricted use, distribution, and reproduction in any medium, provided the original work is properly cited. The Creative Commons Public Domain Dedication waiver (http://creativecommons.org/publicdomain/ zero/1.0/) applies to the data made available in this article, unless otherwise stated. 